\title{
SELECTED DIETARY FACTORS AND BREAST CANCER RISK
}

\author{
WYBRANE ŻYWIENIOWE CZYNNIKI RYZYKA RAKA PIERSI
}

\author{
Medical University of Gdańsk, Department of Hygiene and Epidemiology \\ Gdański Uniwersytet Medyczny, Zakład Higieny i Epidemiologii;
}

\begin{abstract}
While breast cancer is the most common cancer in women around the world, it is necessary to know the nutritional factors that can have both protective and negative effects on the risk of breast cancer. Unfortunately, the results of the research still do not give a definite answer to the question: which food products or food ingredients reduce, and which increase the risk of breast cancer. At a time when the main source of knowledge of health for the majority of society is the internet, myths about this disease are still being replicated. Only on the basis of clear scientific evidence can we build an effective prevention program that can save millions of women from breast cancer. In this review, we decided to present nutritional risk factors whose impact on the risk of breast cancer was examined, however, the results are not conclusive, like: fibre, milk products
\end{abstract}

Key words: breast cancer, nutritional risk factors, review, fibre, milk products

\section{STRESZCZENIE}

Podczas gdy rak piersi jest najczęstszym nowotworem u kobiet na całym świecie, konieczne jest poznanie czynników żywieniowych, które mogą mieć zarówno ochronny, jak i negatywny wpływ na ryzyko raka piersi. Niestety, wyniki badań wciąż nie dają jednoznacznej odpowiedzi na pytanie, które produkty spożywcze lub składniki żywności zmniejszają, a które zwiększają ryzyko raka piersi. W czasach, gdy głównym źródłem wiedzy o zdrowiu dla większości społeczeństwa jest internet, mity o tej chorobie wciąż są powielane. Tylko na podstawie jasnych dowodów naukowych możemy stworzyć skuteczny program profilaktyczny, który może uratować miliony kobiet przed rakiem piersi. W niniejszej pracy przedstawiono żywieniowe czynniki, których wpływ na ryzyko raka piersi wielokrotnie badano, jednak wyniki tych analiz często wzajemnie się wykluczają. Dokonano przeglądu badań nad wpływem takich czynników jak: błonnik, produkty mleczne

Slowa kluczowe: rak piersi, żywieniowe czynniki ryzyka, błonnik, produkty mleczne

\section{INTRODUCTION}

Breast cancer is the most common cancer diagnosed among women and is also the leading cause of cancer death among women. In 2018, on the whole world were diagnosed approximately 2.1 million new cases. $(1,2,3)$. The incidence rate of breast cancer ranges from 19.4 per 100,000 people in East Africa to 89.7 per 100,000 in West Europe (4). Figures in Europe indicate that the absolute number of new diagnosis and deaths due to this disease continues to increase (5). This situation also applies to Poland, where the survival rate is significantly lower than in other European countries (5).

\section{WPROWADZENIE}

Rak piersi jest najczęściej diagnozowanym nowotworem u kobiet $i$ jednocześnie jest najczęstszą przyczyną zgonów z powodu raka u kobiet na świecie. W 2018 roku na całym świecie zdiagnozowano w przybliżeniu 2,1 miliona nowych przypadków $(1,2,3)$. Zapadalność na raka piersi waha się od 19,4 na 100000 ludzi w Afryce Wschodniej do 89,7 na 100000 w Europie Zachodniej (4). Liczby w Europie wskazują, że bezwzględna liczba nowych przypadków i zgonów z powodu tej choroby nadal rośnie (2). Sytuacja ta dotyczy również Polski, gdzie dodatkowo przeżywalność jest istotnie niższa niż w innych krajach europejskich (5). 
Epidemiological studies suggests that breast cancer is a multifactorial disease. Among the known risk factors are listed: genetic, reproductive and environmental factors (1). Breast cancer can be due to unhealthy lifestyles (6). An important element of the lifestyle is diet, the impact of which on the risk of breast cancer is one of the more frequently studied and more important factors underlying this disease (7). Data published by the International Agency for Research on Cancer (IARC) show that an improper diet was the cause of about $1 / 4$ of cases of breast cancer (8). However, the impact of nutrition on the risk of breast cancer has still not been fully understood (9). The only well- established diet- related risk factors for breast cancer are obesity and alcohol consumption. However, despite many studies and colloquial beliefs, the results regarding the impact of fiber, milk and dairy products on the risk of breast cancer are not clear. The purpose of this study is to summarize current knowledge about the effects of fiber and milk and dairy products on the risk of breast cancer.

\section{MATERIAL AND METHOD}

An unsystematic review was carried out. An electronic literature search was conducted in Medline/ PubMed, Google Scholar to identify human studies written in the English language and published in 1982-2018, that included the following keywords or phrases: breast cancer, epidemiology of breast cancer, diet and risk of breast cancer, fiber and risk of breast cancer, milk and dairy products and risk of breast cancer, , dietary patterns and risk of breast cancer. The MEDLINE searches were supplemented by searching for related articles referenced in relevant published studies and reviews. To be included in the review, a study must have been published in English, with a case-control, cohort, cross sectional study design or the previous meta- analysis and with the primary outcome of breast cancer. Authors read the abstracts of the articles retrieved in the initial search to identify studies that examined consumption of fibre, milk and dairy products and breast cancer risk. Only studies (20) that reported risk estimates (hazards ratios, odds ratios (ORs), and relative risks (RR)) of breast cancer and measures of variability (SEs or $95 \%$ CIs from which these could be derived) were included.

\section{RESULTS}

\section{High fibre intake and the risk of breast cancer}

Dietary fibre is a term that is used for plant-based carbohydrates that are not digested in the small intestine. It also includes other plant components like lignin. Dietary fiber has been hypothesized to reduce the risk of breast
Badania epidemiologiczne sugerują, że rak piersi jest chorobą wieloczynnikową. Wśród uznanych przyczyn wymienia się: czynniki genetyczne, reprodukcyjne i środowiskowe (1). Niebagatelną rolę odgrywa również styl życia (6). Jego istotnym elementem jest dieta, której wpływ na ryzyko raka piersi jest jednym z częściej badanych i ważniejszych czynników tej choroby (7). Dane opublikowane przez Międzynarodową Agencję Badań nad Rakiem (IARC) wykazały, że niewłaściwa dieta była przyczyną około 1/4 przypadków raka piersi na świecie (8). Jednakże wpływ sposobu żywienia na ryzyko raka piersi wciąż nie został do końca poznany (9). Wśród dobrze udokumentowanych czynników wymienia się otyłość oraz konsumpcję alkoholu. Natomiast pomimo wielu badań i funkcjonujących potocznie przekonań wyniki dotyczące wpływu błonnika oraz mleka i produktów mlecznych na ryzyko raka piersi nie są jednoznaczne. Celem obecnej pracy jest podsumowanie bieżącej wiedzy dotyczącej wpływu błonnika oraz mleka i produktów mlecznych na ryzyko raka piersi .

\section{MATERIAŁ I METODA}

Dokonano przeglądu niesystematycznego artykułów indeksowanych w bazach : Medline/ PubMed, Google Scholar opublikowanych w latach 1982- 2018 w języku angielskim. Wyszukiwane frazy: rak piersi, epidemiologia raka piersi, żywieniowe czynniki ryzyka raka piersi, błonnik a ryzyko raka piersi, mleko i produkty mleczne a ryzyko raka piersi, dieta a rak piersi. . Wyszukiwania w bazach zostały uzupełnione wyszukiwaniem powiązanych artykułów, do których się odwoływało odpowiednie opublikowane badanie. Kryteria włączenia do przeglądu: badanie musiało być opublikowane w języku angielskim, z projektu badania kliniczno- kontrolnego, kohortowego, przekrojowego lub przeprowadzonej wcześniej metaanalizy oraz dotyczyć przypadków pierwotnego raka piersi.

Autorzy przeczytali streszczenia artykułów uzyskanych podczas wstępnych poszukiwań, aby zidentyfikować badania, w których analizowano wpływ spożycia błonnika, mleka i produktów mlecznych na ryzyko raka piersi. Uwzględniono jedynie te badania (20), w których dokonano oszacowania ryzyka (współczynniki ryzyka, iloraz szans (OR) i ryzyko względne) raka piersi oraz miary zmienności (SE lub 95\% CI, z których można je wyprowadzić).

\section{WYNIKI}

Wysokie spożycie błonnika a ryzyko raka piersi Błonnik pokarmowy to pojęcie stosowane w przypadku węglowodanów pochodzenia roślinnego, które nie są trawione w jelicie cienkim. Obejmuje również inne składniki roślinne, takie jak lignina. Już ponad trzy dekady temu 
cancer over three decades ago (10), but the protective effect on breast cancer risk is currently inconclusive. The World Cancer Research Fund International review panel in 2017 placed fiber in the group of "evidence limitedno conclusion" (11). Soluble fiber is contained in oats, legumes and seaweeds; insoluble- in seeds and whole grains. Fruits and vegetables contain a large amount of dietary fiber, for which mechanistic data support the plausibility of a protective effect on breast cancerogenesis, especially for vegetable fiber, due to their compination of soluble and insoluble fibers in equal proportions $(12,13)$. The results of a large prospective American study the National Institutes of Health-AARP (American Association of Retired Persons ) Diet and Health Study suggest that dietary fiber intake was associated with a $13 \%$ lower risk of breast cancer in postmenopausal women with the highest intake of total dietary fiber $(26 \mathrm{~g} /$ day) as opposed to the lowest intake of dietary fiber (11g/day). The association appeared to be stronger for lobular tumors than that for ductal tumors and for $\mathrm{ER}^{-} /$ $\mathrm{PR}^{-}$tumors than for $\mathrm{ER}^{+} / \mathrm{PR}^{+}$tumors. Total fat intake did not significantly modify the association between dietary fiber intake and risk of breast cancer (14). Different results were provided by The Nurses' Health Study (4092 women), which showed no relationship between total fiber intake and fiber type and breast cancer (15). In the Japan Public Health Center- based Prospective Study extreme high intake of total fiber $(>18 \mathrm{~g} /$ day) was associated with decreased risk of breast cancer (16). Also some case- control studies have suggested that high intakes of fiber may reduce the risk of $\mathrm{BC}(17,18)$ but most prospective cohort studies have found no relation between dietary fiber intake and breast cancer in postmenopausal women, some studies did suggest an inverse association (19-21). Other studies showed that adolescent dietary fiber, vegetable protein, vegetable fat, and nut intakes were each associated with a reduced risk of breast cancer (22). To similar conclusions came researchers in the Nurses' Health Study II- they suggested that higher fiber intakes during adolescence and early adulthood are associated with reduced $\mathrm{BC}$ incidence in women. The associations were apparent for most sources of fiber and were independent of other dietary factors and healthy eating behavior. Several biological mechanisms support the beneficial role of dietary fiber on $\mathrm{BC}$ risk $(16,23)$. The results of the presented studies do not clearly indicate the protective effect of fiber on breast cancer (tab. I). This protective effect may be related to the fact that eating fiber-rich foods reduces the risk of obesity, which has been recognized as one of the factors that increase the risk of post-menopausal breast cancer. In the majority of analyzes, women consuming a sufficient amount of this ingredient had normal body mass, did not smoke, drink alcohol and declared regular physical activity. Controversy may also be raised by research on fiber sugerowano, iż błonnik pokarmowy zmniejsza ryzyko zachorowania na raka piersi (10), jednakże mechanizm działania ochronnego nie został do końca poznany. Światowy panel kontrolny World Cancer Research Fund w 2017 r. umieścił błonnik pokarmowy w grupie „dowodów ograniczonych” (11).

Rozpuszczalny błonnik zawarty jest w owsie, roślinach strączkowych i wodorostach morskich; nierozpuszczalny w nasionach i pełnych ziarnach. Owoce i warzywa zawierają dużą ilość błonnika pokarmowego, dla którego dane mechanistyczne potwierdzają wiarygodność ochronnego wpływu na proces nowotworzenia piersi, zwłaszcza w odniesieniu do błonnika, którego źródłem są warzywa, ze względu na to, że włókna rozpuszczalne i nierozpuszczalne występują w równych proporcjach $(12,13)$. Wyniki dużego prospektywnego amerykańskiego badania Narodowego Instytutu Zdrowia AARP (American Association of Retired Persons), dotyczacego diety i zdrowia, sugerują, że spożycie błonnika było związane z o $13 \%$ niższym ryzykiem raka piersi u kobiet po menopauzie, z najwyższym spożyciem całkowitym błonnika pokarmowego (26 g/dzień) w porównaniu do najniższego spożycia błonnika pokarmowego (11g/dzień). Związek ten okazał się silniejszy w przypadku guzów zrazikowych niż guzów przewodowych i guzów ER- / PR- niż guzów $\mathrm{ER}+/ \mathrm{PR}+$. Całkowite spożycie thuszczów nie wpłynęło istotnie na związek pomiędzy spożyciem błonnika a ryzykiem raka piersi (14). Odmiennych wyników dostarczyło badanie The Nurses' Health Study (4092 kobiet), w którym nie wykazano związku pomiędzy spożyciem błonnika ogółem oraz rodzajem błonnika a rakiem piersi (15). Natomiast w badaniu prospektywnym przeprowadzonym przez Japan Public Health Center zauważono, iż wysokie spożycie błonnika całkowitego ( $>18 \mathrm{~g} /$ dzień) wiązało się $\mathrm{z}$ istotnie mniejszym ryzykiem raka piersi, jednakże pozostałe obserwacje nie były istotne statystycznie (16). Niektóre badania kliniczno-kontrolne również sugerują, że wysokie spożycie błonnika może zmniejszać ryzyko raka piersi $(17,18)$, jednakże większość prospektywnych badań kohortowych nie znalazła związku między spożyciem błonnika a rakiem piersi u kobiet po menopauzie. Niektóre z nich sugerowały odwrotną zależność (19-21). Odrębne badania zostały przeprowadzone wśród młodych kobiet. Wykazano w nich, że spożywanie takich składników jak: błonnik, białko i tłuszcz, których źródłem są warzywa a także konsumpcja orzechów w okresie dojrzewania wiążą się ze zmniejszonym ryzykiem raka piersi (22). Do podobnych wniosków doszli naukowcy w badaniu Nurses ,Health Study II - sugerowali, że większe spożycie błonnika w okresie dojrzewania i wczesnej dorosłości związane jest ze zmniejszoną częstością raka piersi u kobiet. Związki były widoczne dla większości źródeł błonnika i były niezależne od innych czynników żywieniowych i zdrowego odżywiania (23). Na podstawie cytowanych badań nie możemy jednak jednoznacznie określić, czy wysokie spożycie błonnika zmniejsza ryzyko wystąpienia raka piersi (tab. I). 
Tab. I Summary of 11 studies that evaluated association betwen fiber consumption and risk of breast cancer

Tab. I Przegląd 11 badań oceniających związek pomiędzy spożyciem błonnika a ryzykiem raka piersi.

\begin{tabular}{|c|c|c|c|c|c|c|c|c|}
\hline Study & Type of study & Country & Menopausal status & Sample size & $\begin{array}{l}\text { Type (n) of } \\
\text { breast cancer }\end{array}$ & Results & $\mathrm{p}$ & $\begin{array}{c}\text { fiber type / dose / } \\
\text { source }\end{array}$ \\
\hline Y. Park et al. & prospective & USA & Postmenop. & 5461 & $\begin{array}{l}\text { ER-/PR- } \\
(366) \\
\text { ER+/PR+ } \\
(1641) \\
\text { Lobular } \\
\text { Ductal }\end{array}$ & $\begin{array}{l}\mathrm{RR}=0.87 ; 95 \% \mathrm{CI}: \\
0.77 ; 0.98 \\
\\
\mathrm{RR}=0.56 ; 95 \% \mathrm{CI}: \\
0.35 ; 0.90 \\
\\
\mathrm{RR}=0.95 ; 95 \% \mathrm{CI}: \\
0.76 ; 1.2 \\
\\
\mathrm{RR}=0.66 ; 95 \% \mathrm{CI}: \\
0.44 ; 0.97 \\
\mathrm{RR}=0.90 ; 95 \% \mathrm{CI}: \\
0.77 ; 1.04\end{array}$ & $\begin{array}{l}0,008 \\
0,47 \\
0.04 \\
0.1\end{array}$ & $\begin{array}{l}\begin{array}{l}\text { Soluble } \\
\text { (p 0.02) }\end{array} \\
\text { Total- no asso- } \\
\text { ciation was found } \\
\text { between fiber from } \\
\text { grains, vegetables, } \\
\text { fruits and beans and } \\
\text { the risk of breast } \\
\text { cancer }\end{array}$ \\
\hline $\begin{array}{l}\text { Holmes } \\
\text { MD et al. }\end{array}$ & prospective & USA & Premenop. & 4092 & Total cases & $\begin{array}{l}\mathrm{RR}=0.98 ; 95 \% \mathrm{CI}: \\
0.87 ; 1.11 \\
\text { RR=0.68; } \\
\text { 95\%CI: } 0.43,1.06\end{array}$ & 0.79 & $\begin{array}{l}\text { total } \\
>30 \mathrm{~g} / \mathrm{d} \\
\text { versus } \\
\leq 10 \mathrm{~g} / \mathrm{d}\end{array}$ \\
\hline Narita S. et al. & prospective & Japan & Pre- and postmenop. & 41501 & $\begin{array}{l}\text { Total cases } \\
\\
\text { ER-/PR- } \\
(91) \\
\text { ER+/PR+ } \\
(157)\end{array}$ & $\begin{array}{l}\mathrm{HR}=0.78 ; 95 \% \mathrm{CI}: \\
0.55 ; 1.09 \\
\\
\mathrm{HR}=0.63 ; 95 \% \mathrm{CI}: \\
0.40 ; 0.98 \\
\text { HR:5.45; } 95 \% \mathrm{CI}: \\
1.02 ; 29.20 \\
\text { HR: } 1.03 ; 95 \% \mathrm{CI}: \\
0.41 ; 2.57\end{array}$ & $\begin{array}{l}0.04 \\
0.03\end{array}$ & $\begin{array}{l}\text { total- highest/ } \\
\text { lowest intake }\end{array}$ \\
\hline $\begin{array}{l}\text { Baghurst } \\
\text { PA et al } \\
\text { La Vecchia C. } \\
\text { et al. }\end{array}$ & $\begin{array}{l}\text { Case- control } \\
\text { Case- control }\end{array}$ & $\begin{array}{l}\text { Australia } \\
\text { Italy }\end{array}$ & $\begin{array}{l}\text { Postmenop. } \\
\text { Pre- and postmenop. }\end{array}$ & $\begin{array}{l}451 \\
2569-\text { cases } \\
2588-\text { controls }\end{array}$ & $\begin{array}{l}\text { Total cases } \\
\text { Total cases }\end{array}$ & $\begin{array}{l}\mathrm{RR}=0.46 \\
\text { OR:0.94; 95\%CI: } \\
0.86 ; 1.02\end{array}$ & $\begin{array}{l}0.80 \\
<0.001\end{array}$ & $\begin{array}{l}\text { Total } \\
\text { Total }\end{array}$ \\
\hline $\begin{array}{l}\text { Verhoeven DT } \\
\text { et al. }\end{array}$ & prospective & Netherlands & Postmenop. & 62573 & Total cases & RR: 1.99 & $<0,05$ & Soluble \\
\hline Cade JE et al., & Case- control & UK & Pre- and postmenop. & 35792 & $\begin{array}{l}\text { Total cases } \\
\text { Premenop }\end{array}$ & $\begin{array}{l}\text { HR:0.48; } \\
\text { 95\%CI: } 0.24 ; 0.96 \\
\text { HR:0.33; 95\%CI: } \\
0.14 ; 0.79\end{array}$ & $\begin{array}{l}0.16 \\
0.01\end{array}$ & $\begin{array}{l}\text { Total } \\
\\
\text { Total } \\
>30 \mathrm{~g} / \mathrm{d} \\
\text { versus }<20 \mathrm{~g} / \mathrm{d}\end{array}$ \\
\hline Ying Liu et al. & Case- control & Canada & Pre- and postmenop. & $\begin{array}{l}\text { 2865- przyp. } \\
\text { 3299- kontr. }\end{array}$ & Total cases & $\begin{array}{l}\text { OR:0.66; 95\%CI: } \\
0.55 ; 0.78\end{array}$ & 0.003 & \\
\hline $\begin{array}{l}\text { Farvid MS } \\
\text { et al. }\end{array}$ & prospective & USA & $\begin{array}{l}\text { Premenop. } \\
\text { 1.Adolescence } \\
\text { 2. Early adult life } \\
3.1+2\end{array}$ & 90534 & & $\begin{array}{l}\text { 1.RR:0.84; } \\
\text { 95\%CI: } 0.70 ; 1.01 \\
\text { 2.RR:0.81; } \\
\text { 95\%CI: } 0.72 ; 0.91 \\
\text { RR:0.86; 95\%CI: } \\
\text { 0.77;0.97 } \\
\text { RR:0.80; 95\%CI: } \\
\text { 0.71;0.90 } \\
\text { 3.RR:0.75; } \\
\text { 95\%CI: } 0.62 ; 0.91\end{array}$ & $\begin{array}{l}<0.0001 \\
0.04 \\
0.002 \\
0.02 \\
<0.001\end{array}$ & $\begin{array}{l}\text { Total } \\
\text { Total } \\
\text { Soluble } \\
\text { Insoluble }\end{array}$ \\
\hline Ferrari P et al. & prospective & Europe & Pre- and postmenop. & $\begin{array}{l}\text { 250-cases, } \\
250 \text {-controls } \\
11576\end{array}$ & $\begin{array}{l}\text { Total cases } \\
\text { Total cases } \\
\text { ER-/PR- } \\
\text { ER+/PR+ }\end{array}$ & $\begin{array}{l}\text { OR }=0.60 ; \\
95 \% C \mathrm{CI}: 0.47 ; 0.75 \\
\text { OR=0.81; } 95 \% \text { CI: } \\
0.66 ; 0.99 \\
\\
\text { HR }=0.95 ; 95 \% \mathrm{CI}: \\
0.89 ; 1.01 \\
\text { HR }=0.90 ; 95 \% \mathrm{CI}: \\
0.84 ; 0.96 \\
\mathrm{HR}=0.74 ; 95 \% \mathrm{CI}: \\
0.59 ; 0.93 \\
\text { HR }=0.92 ; 95 \% \mathrm{CI}: \\
0.81 ; 1.03\end{array}$ & $\begin{array}{l}0.004 \\
0.03 \\
<0.01 \\
0.01 \\
0.03\end{array}$ & $\begin{array}{l}\text { Total } \\
\text { Whole grain, vege- } \\
\text { tables and fruits } \\
\text { Fish and olive oil } \\
\text { Total } \\
\text { Vegetables } \\
\text { Vegetables }\end{array}$ \\
\hline & & & & & & & & Vegetables \\
\hline
\end{tabular}


intake in youth. Interviews of adult women regarding the presence of this component in the diet during adolescence or early adulthood may not be a real reflection of how they were fed from 30 years ago. In the cancer epidemic era, high fiber intake could be a very simple element of the primary prevention chain - but this theory requires confirmation in prospective studies, because at the moment it is still closer to myth than reality.

\section{Milk and dairy products and the risk of breast cancer}

Dairy foods are important sources of several nutrients that could favorably affect cancer risk, including vitamin $\mathrm{D}$, calcium, conjugated linoleic acid, butyrate, and other nutrients and phytochemicals, but they also contain substances, such as insulin-like growth factor 1 (IGF-1) and other growth hormones, saturated fatty acid and some of exogenous such as pesticides that may adversely affect risk (24- 26). Several studies analyzed the relationship between dairy products and the risk of breast cancer, but the evidence on dairy consumption and breast cancer is inconsistent. Some studies suggested that skimmed and fermented products could reduce the risk of disease, but from the other side high intake of whole milk can involved in the development of breast cancer (26- 28, 34). In large Swedish cohort study, the risks of breast cancer were significantly decreased among individuals with lactose intolerance, whereas the incidences in their siblings and parents were similar compared with the general population (29). Meta- analysis of 18 prospective cohort studies suggested that the associations were somewhat stronger for low-fat dairy intake than for high-fat dairy intake and for premenopausal women than for postmenopausal women. They found that increased consumption of total dairy food, but not milk, may be associated with a reduced risk of breast cancer (30). In the Cancer Prevention Study II Nutrition Cohort high intake of dietary calcium and low-fat dairy products was associated with a moderately lower risk of developing postmenopausal breast cancer compared with women with lowest intake levels. Postmenopausal women, who consumed greater intakes of dietary calcium and dairy products, primarily from low- fat source, were at lower risk of breast cancer (31). The analysis of the association between meat and dairy products consumption and the risk of breast cancer did not link the relationship between any type of dairy products and breast cancer (32). An examination of results from more than 40 case- control studies and 12 cohort studies also does not support an association between dairy products consumption and the risk of breast cancer (33). Therefore, it cannot be unambiguously determined what (if any) compound has dairy products intake with the risk of breast cancer (tab. II). The harmful effect of dairy products, suggested repeatedly in the media, has not been supported in any
Przedstawiony protekcyjny efekt może mieć związek z faktem, iż spożywanie produktów bogatych w błonnik zmniejsza ryzyko otyłości, która została uznana jako jeden z czynników zwiększających ryzyko pomenopauzalnego raka piersi. W większości analiz kobiety spożywające dostateczną ilość tego składnika miały prawidłową masę ciała, nie paliły papierosów, nie spożywały alkoholu oraz deklarowały regularną aktywność fizyczną. Kontrowersje mogą budzić również badania nad spożyciem błonnika w młodości. Przeprowadzone wywiady wśród dorosłych kobiet dotyczące obecności w diecie tego składnika w okresie dojrzewania lub wczesnej dorosłości mogą nie być rzeczywistym odzwierciedleniem sposobu żywienia sprzed 30 lat. W erze epidemii raka piersi- wysokie spożycie błonnika mogłoby stanowić bardzo prosty element łańcucha profilaktyki pierwotnej- teoria ta wymaga jednak potwierdzenia $\mathrm{w}$ badaniach prospektywnych, ponieważ w chwili obecnej wciąż bliżej jej do mitu niż rzeczywistości.

\section{Mleko i produkty mleczne a ryzyko raka piersi}

Produkty mleczne zawierają wiele składników odżywczych, które mogą zmniejszać ryzyko zachorowania na raka, w tym witaminę $\mathrm{D}$, wapń, sprzężony kwas linolowy, maślany i inne składniki odżywcze i fitochemiczne, ale z drugiej strony zawierają również substancje, takie jak insulinopodobny czynnik wzrostu 1 (IGF- 1) i inne hormony wzrostu, nasycone kwasy thuszczowe i niektóre składniki egzogenne, takie jak pestycydy, które mogą niekorzystnie wpływać na ryzyko raka piersi (24-26). W kilku badaniach analizowano związek między spożyciem produktów mlecznych a ryzykiem raka piersi, ale dostarczone dowody są niespójne. Niektóre badania sugerowały, że odthuszczone i sfermentowane produkty mogą zmniejszać ryzyko choroby, ale z drugiej strony wysokie spożycie pełnego mleka może zwiększać ryzyko rozwoju raka piersi (26-28,34). W dużym szwedzkim badaniu kohortowym ryzyko wystąpienia raka piersi było znacząco niższe u osób z nietolerancją laktozy, natomiast zapadalność ich rodzeństwa i rodziców była zbliżona do tej w populacji ogólnej (29). Metaanaliza 18 prospektywnych badań kohortowych sugerowała, że te skojarzenia były nieco mocniejsze w przypadku spożywania niskotłuszczowych produktów mlecznych niż w przypadku spożywania produktów mlecznych o wysokiej zawartości thuszczu i w przypadku kobiet przed menopauzą niż w przypadku kobiet po menopauzie. Stwierdzono, że zwiększone spożycie produktów mlecznych (nie mleka), może wiązać się ze zmniejszonym ryzykiem raka piersi (30). W badaniu Cancer Prevention Study II Nutrition Cohort wysokie spożycie wapnia i niskotłuszczowych produktów mlecznych wiązało się z umiarkowanie niższym ryzykiem zachorowania na raka piersi po menopauzie $\mathrm{w}$ porównaniu $\mathrm{z}$ kobietami o najniższym poziomie spożycia tych produktów. 
Tab. II Summary of 9 studies that evaluated the association between milk and dairy products consumption and risk of breast cancer Tab. II Przegląd 9 badań oceniających związek pomiędzy spożyciem mleka i produktów mlecznych a ryzykiem raka piersi

\begin{tabular}{|c|c|c|c|c|c|c|c|}
\hline Study & Country & Type of study & Sample size & $\begin{array}{c}\text { Menopausal } \\
\text { status }\end{array}$ & Factors evaluated & Exposure levels and results & $\mathrm{p}$ \\
\hline $\begin{array}{l}\text { Maliou D } \\
\text { et al, }\end{array}$ & Algeria & Case-control & $\begin{array}{l}184 \text {-case } \\
184 \text { contr. }\end{array}$ & $\begin{array}{l}\text { Pre- and } \\
\text { postmenop. }\end{array}$ & $\begin{array}{l}\text { Milk } \\
\text { Cheese total } \\
\text { Fresh cheese } \\
\text { Yogurt } \\
\text { Fermented milk } \\
\text { Dairy products total }\end{array}$ & $\begin{array}{l}387,75 \mathrm{~g} / \mathrm{d} \text { versus } 75,22 \mathrm{~g} / \mathrm{d} \\
\text { OR:2.61 95\%CI: } 1.32,5.16 \\
41,1 \mathrm{~g} / \mathrm{d} \text { versus } 6,13 \mathrm{~g} / \mathrm{d} \\
\text { OR:0.38 95\%CI: } 0.18,0.78 \\
\text { 14g/d versus } 0 \mathrm{~g} / \mathrm{d} \text { OR:0.24 } \\
\text { 95\%CI: } 0.12,0.51 \\
\text { 100g/d versus } 0 \mathrm{~g} / \mathrm{d} \text { OR:0.6 } \\
\text { 95\%CI: } 0.31,1.15 \\
\text { 42,92g/d versus } 6,13 \mathrm{~g} / \mathrm{d} \\
\text { OR:0.61 95\%CI: } 0.32,1.17 \\
609,62 \mathrm{~g} / \mathrm{d} \text { versus } 184,42 \mathrm{~g} / \mathrm{d} \\
\text { OR: } 1.595 \% \mathrm{CI}: 0.77,2.92\end{array}$ & $\begin{array}{l}0.027 \\
0.066 \\
0.001 \\
0.087 \\
0.328 \\
0.154\end{array}$ \\
\hline $\begin{array}{l}\text { Ronco AL } \\
\text { et al. }\end{array}$ & Urugwaj & Case-control & $\begin{array}{l}\text { 111-case } \\
222 \text {-contr. }\end{array}$ & & $\begin{array}{l}\text { Milk } \\
\text { Chocolate milk } \\
\text { Cheese danbo } \\
\text { Cheese gruyere } \\
\text { Ice cream } \\
\text { Yogurt low- fat } \\
\text { Yogurt } \\
\text { Cheese ricotta } \\
\text { Butter }\end{array}$ & $\begin{array}{l}\text { OR:2.84, 95\%CI: } 1.38,5.84 \\
\text { OR:2.85, 95\%CI: } 1.06,7.69 \\
\text { OR:1.66, 95\%CI: } 0.86,3.19 \\
\text { OR:1.93, 95\%CI: } 1.05,3.55 \\
\text { OR:1.98, 95\%CI: } 1.07,3.66 \\
\text { OR:0.29, 95\%CI: } 0.15-0.58 \\
\text { OR:0.41, 95\%CI: } 0.22,0.79 \\
\text { OR:0.45, 95\%CI: } 0.24,0.83 \\
\text { OR:0.49, 95\%CI: } 0.23,1.07\end{array}$ & \\
\hline $\begin{array}{l}\text { Zhang CX } \\
\text { et al. }\end{array}$ & China & Case-control & $\begin{array}{l}\text { 438- case } \\
438 \text { - contr. }\end{array}$ & & $\begin{array}{l}\text { No significant } \\
\text { differences }\end{array}$ & & \\
\hline Ji J et al. & Sweden & Prospective & 118 & $\begin{array}{l}\text { Postmen.; } \\
\text { lactose } \\
\text { intolerance }\end{array}$ & Dairy products total & $\mathrm{SIR}=0.79 ; 95 \% \mathrm{CI}: 0.65,0.94$ & \\
\hline $\begin{array}{l}\text { Dong JY } \\
\text { et al. }\end{array}$ & & Meta-analysis & 24181 & & $\begin{array}{l}\text { Dairy products total } \\
\text { Milk }\end{array}$ & $\begin{array}{l}\text { RR:0.85, 95\%CI: } 0.76,0.95 \\
\text { RR:0.91, 95\%CI: } 0.80,1.02\end{array}$ & $\begin{array}{l}0.01 \\
0.003\end{array}$ \\
\hline $\begin{array}{l}\text { McCullough } \\
\text { ML et al. }\end{array}$ & USA & Prospective & 68567 & & Dairy products total & $\begin{array}{l}2 \text { or more serving of dairy } \\
\text { products per day versus } 0,5 \\
\text { serving per day RR: } 0.81, \\
95 \% \text { CI: } 0.69,0.95\end{array}$ & 0.002 \\
\hline $\begin{array}{l}\text { Missmer SA } \\
\text { et al. }\end{array}$ & $\begin{array}{l}\text { Ameryka } \\
\text { Pn Europa } \\
\text { Zachodnia }\end{array}$ & Prospective & 351041 & & $\begin{array}{l}\text { Masło } \\
\text { Milk } \\
\text { Yogurt } \\
\text { Ice cream } \\
\text { High- fat cheese }\end{array}$ & $\begin{array}{l}\text { RR:1.02; 95\%CI: } 0.95,1.10 \\
\text { RR:0.99; 95\%CI: } 0.96,1.01 \\
\text { RR:0.98; 95\%CI: } 0.94,1.01 \\
\text { RR:1.03; 95\%CI: } 0.88,1.22 \\
\text { RR:1.03; 95\%CI: } 0.95,1.11\end{array}$ & $\begin{array}{l}0.04 \\
0.53 \\
0.84 \\
0.37 \\
0.47\end{array}$ \\
\hline $\begin{array}{l}\text { McCann SE } \\
\text { et al. }\end{array}$ & USA & Case-control & $\begin{array}{l}\text { 1941-cases } \\
1237 \text {-contr. }\end{array}$ & & $\begin{array}{l}\text { Dairy products total } \\
\text { Yogurt } \\
\text { Cheese }\end{array}$ & $\begin{array}{l}>42 \text { servings/month versus } \\
<14 \text { servings/month OR:0.85; } \\
\text { 95\%CI: } 0.68,1.06 \\
\text { OR:0.61, 95\%CI: } 0.46,0.82 \\
\text { OR: } 1.53 \text {, 95\%CI: } 0.99,2.34\end{array}$ & 0.05 \\
\hline Zang $\mathrm{J}$ et al. & $\begin{array}{l}\text { USA, Euro- } \\
\text { pa zachod- } \\
\text { nia, Azja }\end{array}$ & Meta-analysis & & & $\begin{array}{l}\text { Dairy products total } \\
\text { Milk } \\
\text { Yogurt } \\
\text { Cheese/butter }\end{array}$ & $\begin{array}{l}\text { RR:0.90; 95\%CI:0.83,0.98 } \\
\text { RR:0.99; 95\%CI:0.86,1.16 } \\
\text { RR:0.91; 95\%CI:0.83,0.99 } \\
\text { RR:0.98; 95\%CI:0.89,1.07 }\end{array}$ & $\begin{array}{l}0.111 \\
0.049 \\
0.991 \\
0.044\end{array}$ \\
\hline
\end{tabular}

epidemiological studies and is currently unfounded. Most analyzes suggest a protective effect on skimmed milk products in relation to breast cancer, therefore, their participation in the diet is the most reasonable.

\section{CONCLUSION}

The role of nutrition and individual nutrients in breast cancer is still not fully understood. The results of
Kobiety po menopauzie, których dieta była bogata w wapń i produkty mleczne, głównie o niskiej zawartości thuszczu, były mniej narażone na zachorowanie (31). Natomiast analiza związku między konsumpcją mięsa i produktów mlecznych a ryzykiem raka piersi nie wykazała związku między jakimkolwiek rodzajem produktów mlecznych a rakiem piersi (32). Metaanaliza ponad 40 badań kliniczno-kontrolnych i 12 badań kohortowych również nie potwierdza związku między spożyciem pro- 
the research do not give a definite answer to the question whether dietary ingredients described in this work protect or stimulate the development of breast cancer. The influence of fiber, milk and dairy products intake on the risk of breast cancer is still unclear, depending mainly of the dose, menopausal status and type of food product. However, unification of the results obtained is extremely important in the face of the global increase in breast cancer. A lot of evidence suggests that the promotion of a healthy lifestyle - including dietary recommendations - should be a priority in the prevention of breast cancer, as a cheap, acceptable and non-pharmacological tool. It should also be remembered that the term diet includes not only the type of food consumed, but also the quality of food, method of heat treatment or frequency of consumption.

\section{REFERENCES}

1. Ban KA, Godellas CV. Epidemiology of breast cancer. Surg Oncol Clin N Am 2014;23:409- 22

2. Bray F, Ferlay J, Soerjomataram I, et al. Global Cancer Statistics 2018: GLOBOCAN Estimates of Incidence and Mortality Worldwide for 36 Cancers in 185 Countries. CA Cancer J Clin 2018;68:394-424

3. Ghoncheh M, Pournamdar Z, Salehiniya H. Incidence and Mortality and Epidemiology of Breast Cancer in the World. Asian Pac J Cancer Prev 2016;(S3)43-6

4. WHO. 2015. Breast cancer: prevention and control [Online]

5. Gliniewicz A, Zielińska A, Kwiatkowska K, et al. Survival in women diagnosed with breast and cervical cancer in Poland - compared to European countries, based on CONCORD - 3 Programme. Przegl Epidemiol 2018;72(4):499-508.

6. Chlebowski RT. Nutrition and physical activity influence on breast cancer incidence and outcome. Breast 2013;22, S30-7.

7. Ruiz RB, Hernandez PS. Diet and cancer: risk factors and epidemiological evidence. Maturitas 2014; 77:202-8.

8. Janssens J, Vandeloo M. Breast cancer: a life-time disease Direct and indirect age-related lifestyle risk factors, Journal of Oncology 2009;59(3):159.

9. Coughlin SS, Smith SA. The Impact of the Natural, Social, Built, and Policy Environments on Breast Cancer. J Environ Health Sci 2015;1(3): 1-7.

10. Goldin BR, Adlercreutz H, Gorbach SL, et al. Estrogen excretion patterns and plasma levels in vegetarian and omnivorous women. N Engl J Med 1982;307(25):15421547.

11. World Cancer Research Fund/American Institute for Cancer Research. Diet, Nutrition, Physical Activity and Cancer: a Global Perspective. Continuous Update Project Expert Report 2018.

12. Mourouti N, Papavagelis Ch, Plytzanopoulu P, et al. Dietary patterns and breast cancer: a case- control study in women. Eur J Nutr 2015;54:609- 617 duktów mlecznych a ryzykiem raka piersi (33). W oparciu o dostępną wiedzą niestety wciąż nie można jednoznacznie określić, jaki (jeśli w ogóle) ma wpływ spożycie mleka oraz produktów mlecznych na ryzyko raka piersi (Tab. II). Sugerowany niejednokrotnie w mediach szkodliwy wpływ nabiału nie został poparty w żadnych badaniach epidemiologicznych i w chwili obecnej jest bezzasadny. Większość analiz sugeruje ochronny w stosunku do raka piersi wpływ odthuszczonych produktów mlecznych, dlatego też ich udział $\mathrm{w}$ diecie jest jak najbardziej zasadny.

\section{WNIOSKI}

Rola żywienia i poszczególnych składników odżywczych w raku piersi nadal nie jest w pełni zrozumiała. Wyniki badań nie dają jednoznacznej odpowiedzi na pytanie, czy opisane w niniejszej pracy składniki diety chronią, czy stymulują rozwój raka piersi. Wpływ błonnika oraz mleka i nabiału na ryzyko raka piersi jest nadal niejasny, zależny w dużej mierze od dawki, statusu menopauzalnego oraz rodzaju produktu spożywczego. Unifikacja uzyskanych wyników jest niezwykle ważna w obliczu globalnego wzrostu zachorowalności na raka piersi. Wiele dowodów sugeruje, że promowanie zdrowego stylu życia - w tym zaleceń żywieniowych - powinno być priorytetem w profilaktyce raka piersi, jako tanie, akceptowalne i niefarmakologiczne narzędzie. Należy również pamiętać, że termin „,prawidłowa dieta” obejmuje nie tylko rodzaj spożywanej żywności, ale także jej jakość, metodę obróbki cieplnej oraz częstotliwość spożycia.

13. Ferrari P, Rinaldi S, Jenab M, et al. Dietary fiber and risk of hormonal receptor- defined breast cancer in the European Prospective Investogation into Cancer and Nutrition Study. Am J Clin Nutr 2013;97:344- 53

14. Yikyung Park LA, Brinton AF, Subar A. Dietary fiber intake and risk of breast cancer in postmenopausal women: the National Institutes of Health-AARP Diet and Health Study. Am J Clin Nutr 2009;90(3):664-671

15. Holmes MD, Liu S, Hankinson SE, et al. Dietary carbohydrates, fiber, and breast cancer risk. Am J Epidemiol 2004;159:732-9

16. Saki N, Manami I, Eiko S, et al. Dietary fiber intake and risk of Brest cancer defined by estrogen and progesterone receptor status: the Japan Public Health Center- based Porspective Study. Cancer Causes Control 2017;28:569- 578

17. Baghurst PA, Rohan TE. High- fiber diets and reduced risk of breast cancer, Int J Cancer 1994;56: 173- 176

18. La Vecchia C, Ferraroni M, Franceschi S. Fibers and breast cancer risk. Nutr Cancer 1997;28: 264- 269

19. Verhoeven DT, Assen N, Goldbohm RA, et al. Vitamins $\mathrm{C}$ and $\mathrm{E}$, retinol, beta-carotene and dietary fibre in relation to breast cancer risk: a prospective cohort study. Br J Cancer 1997;75: 149- 55 
20. Cade JE, Burley VJ, Greenwood DC. Dietary fibre and risk of breast cancer in the UK Women's Cohort Study. Int J Epidemiol 2007;36:431-8

21. Lajous M, Boutron-Ruault MC, Fabre A. Carbohydrate intake, glycemic index, glycemic load, and risk of postmenopausal breast cancer in a prospective study of French women. Am J Clin Nutr 2008;87:1384-91

22. Liu Y, Colditz GA, Cotterchio M, et al. Adolescent dietary fiber, vegetable fat, vegetable protein, and nut intakes and breast cancer risk. Breast Cancer Res Treat 2014;145:461-470

23. Farvid MS, Eliassen AH, Cho E, et al. Dietary Fiber Intake in Young Adults and Breast Cancer Risk. Pediatrics 2016;137(3):e20151226.

24. Kongerslev Thorning T, Raben A, Tholstrup T, et al. Milk and dairy products: good or bad for human health? An assessment of the totality of scientific evidence. Food Nutr Res 2016;22;60:32527

25. Chagas CE, Rogero MM, Martini LA. Evaluating the links between intake of milk/dairy products and cancer. Nutr Rev 2012;70:294- 300

26. Maliou D, Belmadi D, Saadi W, et al. Effect of dairy products intake on breast cancer risk: A case- control study in Algeria. Nutrition Clinique at Metabolisme 2018;0985-0562

27. Ronco AL, De Stefani E, Datolli R. Dairy foods and risk of breast cancer: a case- control study in Montevideo, Uruguay. Eur J Cancer Prev 2002;11: 457-63

28. Zhang CX, Ho SC, Fu JH, et al. Dairy products, calcium intake, and breast cancer risk: a case- control study in China. Nutr Cancer 2011;63:12-20

29. J Ji, J Sundquist, K Sundquist (2015): Lactose intolerance and risk of lung, breast and ovarian cancers: aetiological clues from a population-based study in Sweden. Br J Cancer 2015;112(1): 149-152.
30. Dong JY, Zhang L, Ka He, et al. Dairy consumption and risk of breast cancer: a meta-analysis of prospective cohort studies. Breast Cancer Res Treat 2011;127(1): 23-31

31. McCullough ML, Rodriguez C, Diver WR, et al. Dairy, Calcium, and Vitamin D Intake and Postmenopausal Breast Cancer Risk in the Cancer Prevention Study II Nutrition Cohort. Cancer Epidemiol Biomarkers Prev 2005;14(12):2898-904

32. Missmer SA, Smith-Warner SA, Spiegelman D, et al. Meat and dairy food consumption and breast cancer: a pooled analysis of cohort studies. Int $\mathrm{J}$ of Epidemiol 2002;31(1):78-85

33. Parodi WP. Dairy Product Consumption and the Risk of Breast Cancer. J Am Coll Nutr 2005;24(6 Suppl):556S-68S

34. McCann SE, Hays J, Baumgart CW, et al. Usual Consumption of Specific Dairy Foods Is Associated with Breast Cancer in the Roswell Park Cancer Institute Data Bank and BioRepository. Curr Dev Nutr 2017;16;1(3):e000422

Received: 14.11.2018

Accepted for publication: 16.07.2019

Otrzymano: 14.11.2018 r.

Zaakceptowano do publikacji: 16.07.2019 r.

\section{Address for correspondence: \\ Adres do korespondencji:}

Dorota Dydjow-Bendek, Paweł Zagożdżon;

Zakład Higieny i Epidemiologii;

Gdański Uniwersytet Medyczny;

ul. Debinki 7/15; 80-211 Gdańsk; tel.: 583481820. 